\title{
О.В. Сторчило
}

\section{Радіопротекторний ефект їжі в асиміляції вуглеводних субстратів різного ступеня полімерності у двох поколінь нащадків опромінених щурів}

Одеський національний медичний університет, E-mail: alena-61@mail.ru

\begin{abstract}
Досліджували вплив їжі в кишечнику опромінених самців-попередників на функціональну активність тонкої кишки їх нащцадів двох поколінь. Встановлено, щзо ситість тварин під час опромінення визначає радіопротекторний ефект на транспорт вуглеводних субстратів різної міри полімерності лише в нащзадків першого покоління - у другого покоління показники функціональної активності нижче за такі навіть в інтактній групі, переважно за рахунок ферментативної ланки, проте при цььому вони не виходять за межі активної компоненти транспорту. Отже, для захисту наступних поколінь від опромінених попередників необхідні потужніші, ніж просто їжа, радіопротектори. Ключові слова: опромінення; тонка кишка; асимілячзія вуглеводів;нащуадки шурів.
\end{abstract}

\section{ВСТУП}

Іонізуючі випромінювання є природним компонентом довкілля, проте завдяки антропогенному радіоактивному забрудненню радіаційний фон Землі підвищився, в основному в результаті викидів підприємств атомної енергетики і випробувань ядерної зброї. Тому залишається актуальною проблема впливу іонізуючих випромінювань на живі організми. Функціональні порушення внаслідок великих доз опромінення зазвичай проявляються впродовж декількох годин або днів, натомість вади розвитку і інші спадкові хвороби, спричинені ушкодженням генетичного апарату - тільки в наступних поколіннях. Повна ж елімінація негативних наслідків опромінення попередників у популяції відбувається до 7-10-го покоління, причому близько 56\% генетичних хвороб від 1-го покоління проявляються в 2-му [1 - 6]. Проте відомості про трансгенераційний феномен радіаційноіндукованої нестабільності генома у нащадків опромінених у малих дозах батьків нечисленні, суперечливі і вимагають подальшого вивчення [7]. Раніше нами була досліджена активність систем травлення i всмоктування вуглеводних субстратів у тонкій кишці нащадків двох поколінь опромінених голодними самців щурів [8] - була показана стабільність транспорту вільної глюкози у обох поколінь і достовірне зниження активності транспорту М-глюкози, що утворилася при гідролізі мальтози, у нащадків 2-го покоління. Постало питання про те, яку роль у захисті функціональних систем кишки нащадків опромінених тварин може відігравати наявність іжі в кишечнику батьків на момент опромінення. Тому метою цієї роботи стало дослідження показників травлення і всмоктування вуглеводних субстратів різної міри полімерності у нащадків двох поколінь опромінених ситими самців щурів.

\section{МЕТОДИКА}

Досліди проведені на двомісячних щурятах-самцях лінії Вістар масою 50-65 г, яких

(C) О.В. Сторчило 
утримували на стандартному раціоні віварію і які були позбавлені їжі впродовж 18-24 год перед експериментом. Загалом було використано 3 групи по 5 щурят в кожній: 1-ша - інтактні; 2-га - нащадки 1-го покоління від самців, яких було одноразово опромінені ситими (комбікорм) і інтактних самиць [8]; 3-тя - нащадки 2-го покоління. Опромінення самців проводили на телегаммаустановці «Агат-Р-1», потужність дози становила 120 рад/хв, поле - 20 х 20, відстань від джерела до поля - 75 см, доза - 0,5 Гр, час експозиції - 32 с. Акумулюючий препарат слизової оболонки тонкої кишки (АПС) виготовляли за методом Уголева і співав. [9]. Інкубували АПС впродовж 1 год при $37^{\circ} \mathrm{C}$ в оксигенованому середовищі. Як інкубаційне середовище використовували розчини 10 ммоль/л глюкози і 5 ммоль/л мальтози, які готували на розчині Рінгера (pH 7,4). В усі інкубаційні середовища додавали кролячу жовч. Визначали концентрацію вільної глюкози і М-глюкози, утвореної при гідролізі мальтози [10], колориметрично на КФК-2МП ( $\lambda=625$ нм). Після перевірки отриманих результатів на нормальність розподілу за допомогою теста Шапіро-Уілка для статистичної обробки використовували критерій t Стьюдента для незв'язаних вибірок за програмою «Primer Biostatistics».

\section{РЕЗУЛЬТАТИ ТА ЇХ ОБГОВОРЕННЯ}

У попередніх дослідженнях нами було визначено [8], що активність транспортної системи для вільної глюкози у нащадків 1-го покоління опромінених ситими самців щурів була майже на 20 \% вище, ніж в групі на-щадків опромінених голодними самців ( $\mathrm{P}=0,013$; таблиця), при цьому стабільність їі роботи була в 4,5 раза більш високою. Отже, дійсно, наявність їжі в кишечнику самців на момент їх опромінення сприяє підвищенню активності системи транспорту вільної глюкози і стабільності їі роботи у їх нащадків - можливо, через певну механічну захисну дію нутрієнтів і клітковини їжі на мембрани ентероцитів у момент опромінення. Проте це стосується тільки транспортної системи для вільної глюкози, оскільки наявність їжі в кишечнику опромінених самців не впливає на активність мальтози - показники транспорту утвореної М-глюкози в цій групі майже не відрізнялися від таких як у групі нащадків 1-го покоління опромінених голодними самців, так i в інтактній групі. Це справедливо також i для нащадків 2-го покоління опромінених голодними попередників [11]: транспорт вільної глюкози у них майже не відрізнявся від значень у нащадків 1-го покоління, зате транспорт М-глюкози виявився істотно нижчим (на $25 \% ; \mathrm{P}=0,044)$ і менш стабільним (на 56 \%). Ймовірно, це $\epsilon$ проявом накопичених попередниками ушкоджень генома - таке припущення узгоджується 3 даними літератури $[3,6,7]$. При дослідженні впливу ситості самців-попередників на момент опромінення на функціональну активність тонкої кишки їх нащадків 2-го покоління виявилося, що транспортна активність у них відносно вільної глюкози була значно нижча, ніж у нащадків 1-го покоління (на $35 \%$ ) і у інтактних щурят (на $30 \%$ ). При цьому якщо активність транспорту вільної глюкози у нащадків 1-го покоління була навіть дещо вищою, ніж в інтактній групі (на 8\%), то у нащадків 2-го покоління вона була нижчою в 1,5 раза, ніж в попередній групі, і в 1,4 раза щодо значень у інтактних щурят. Розкиди від середнього в цій групі також були удвічі вищими, ніж у групі нащадків 1-го покоління, але все ж таки на 39\% нижчими порівняно з інтактними щурами. Отже, радіопротекторний ефект їжіє дійсним тільки для нащадків 1-го, але не 2-го покоління. Швидше за все, в 2-му поколінні проявляються порушення стабільності генома внаслідок опромінення батьків, що були придбані в рецесивній формі 1-м поколінням, не проявилися в ньому і були передані його нащадкам - це підтверджується даними літератури $[2,4,5,7]$. Це припущення також знаходить підтвердження при аналізі показників 
транспорту М-глюкози: в групі нащадків 2-го покоління вони майже в 1,5 раза (на $32 \%$ ) є нижчими, ніж у нащадків 1-го покоління або у інтактних тварин, на фоні удвічі вищих показників розкидів від середнього. Слід також зауважити, що транспорт М-глюкози в групі інтактних щурят був нижчим, ніж такий вільної глюкози в цій групі на 11\%, порівняно 3 нащадками 2-го покоління - на 13\%, а 3 нащадками 1-го покоління - на 18\%. Отже, наслідки опромінення батьків реалізуються у їх нащадків 2-го покоління дійсно через зниження вмісту мальтози, тобто вражається гідролітична ланка ферментативно-транспортного конвеєру для мальтози, або ж до його складу входить не той транспортер, який відповідає за перенесення вільної глюкози.

Таким чином, ситість батьків на момент опромінення визначає радіопро-текторний ефект насамперед для системи транспорту мономерного вуглеводного субстрату в тонку кишку їх нащадків 1-го покоління - значно стабілізується і підвищується транспорту вільної глюкози (P =0,013) і зберігається транспорт М-глюкози на рівні, визначеному для інтактних тварин. Цього не відбувається у нащадків 2-го покоління - у них виявляється значне зниження показників транспорту обох вуглеводних субстратів у порівнянні 3 такими для інтактної групи $(\mathrm{P}=0,0001$ в

Асиміляція субстратів (ммоль/(л·мг) препаратами слизової оболонки тонкої кишки двомісячних щурят нащадків 1-го и 2-го поколінь від опромінених натще (I) та ситими (II) дозою 0,5 Гр самців та інтактних самиць $(\mathbf{M} \pm \mathbf{m})$.

\begin{tabular}{|c|c|c|}
\hline Група тварин & Глюкоза & Мальтоза \\
\hline \multicolumn{3}{|c|}{ I } \\
\hline \multirow{2}{*}{ Інтактна } & $47,85 \pm 5,59 *$ & $42,71 \pm 2,31 *$ \\
\hline & $11,7 \%$ & $5,4 \%$ \\
\hline \multirow[t]{2}{*}{ Нащадки 1-го покоління } & $\mathrm{x} 42,25 \pm 6,22 *$ & $42,67 \pm 1,95^{*}$ \\
\hline & $14,7 \%$ & $4,6 \%$ \\
\hline \multirow[t]{5}{*}{ Нащадки 2-го покоління } & $\mathrm{xx} 40,35 \pm 4,58 * *$ & $31,77 \pm 3,95 * *$ \\
\hline & $11,4 \%$ & $12,4 \%$ \\
\hline & $\mathrm{P}_{1-3}=0,032$ & $\mathrm{P}_{1-3}=0,0001$ \\
\hline & & $\mathrm{P}_{2-3}=0,0001$ \\
\hline & II & \\
\hline \multirow[t]{2}{*}{ Інтактна } & $47,85 \pm 5,59 *$ & $42,71 \pm 2,31 *$ \\
\hline & $11,7 \%$ & $5,4 \%$ \\
\hline \multirow[t]{3}{*}{ Нащадки 1-го покоління } & $\times 51,97 \pm 1,50 *$ & $42,62 \pm 1,94^{*}$ \\
\hline & $3 \%$ & $4,5 \%$ \\
\hline & $\mathrm{P}_{\mathrm{x}}=0,013$ & \\
\hline \multirow[t]{4}{*}{ Нащадки 2-го покоління } & $\mathrm{xx} 33,47 \pm 2,38$ & $28,99 \pm 2,66$ \\
\hline & $7,1 \%$ & $9,2 \%$ \\
\hline & $\mathrm{P}_{1-3}=0,0001$ & $\mathrm{P}_{1-3}=0,0001$ \\
\hline & $\begin{array}{c}\mathrm{P}_{2-3}=0,0001 \\
\mathrm{P}_{\mathrm{xx}}=0,018\end{array}$ & $\mathrm{P}_{2-3}=0,0001$ \\
\hline
\end{tabular}

*дані отримано раніше [8], використано для зіставлення;

** дані отримано раніше [11], використано для зіставлення;

x відмінність значень у групах нащадків 1-го покоління від опромінених голодними і ситими щурів;

хх відмінність значень у групах нащадків 2-го покоління від опромінених голодними і ситими щурів; В усі інкубаційні середовища додано кролячу жовч. Під показниками асиміляції наведено відсотки розкидів від середнього. 
обох випадках) і для нащадків 1-го покоління ( $\mathrm{P}=0,0001$ в обох випадках), проте показники не опускаються нижче від значень активного транспорту. Отже, дійсно, у 1-му поколінні нащадків опромінених батьків не виявляються отримані від них порушення, незалежно від наявності їжі в кишечнику батьків на момент опромінення, натомість у 2-му поколінні ці порушення є досить яскравими i, всупереч очікуваному, навіть більш вираженими у нащадків опромінених ситими щурів. Вочевидь, наявність їжі у кишечнику батьків при опроміненні здатна захистити їх нащадків тільки не далі 1-го покоління - для захисту наступних поколінь слід використати більш потужні радіопротектори.

Таким чином, ситість на час опромінення самців-попередників визначає радіопротекторний ефект для систем транспорту вуглеводних субстратів різної полімерності тільки у нащадків 1-го покоління - виявлено стимуляцію і значну стабілізацію транспорту вільної глюкози, а також збереження транспорту М-глюкози на рівні, визначеному для інтактних тварин. У нащадків 2-го покоління цей ефект не спостерігається - показники функціональної активності знижуються відносно таких навіть у інтактній групі, проте знаходяться в межах активної компоненти транспорту.

\section{О. В. Сторчило}

\section{РАДИОПРОТЕКТОРНЫЙ ЭФФЕКТ ПИЩИ В АССИМИЛЯЦИИ УГЛЕВОДНЫХ СУБ- СТРАТОВ РАЗНОЙ СТЕПЕНИ ПОЛИМЕР- НОСТИ У ДВУХ ПОКОЛЕНИЙ ПОТОМСТ- ВА ОБЛУЧЕННЫХ КРЫС}

Исследовали влияние пищи в кишечнике облученных самцов-предшественников на функциональную активность тонкой кишки их потомства двух поколений. Установлено, что сытость этих животных во время облучения определяет радиопротекторный эффект на транспорт углеводных субстратов разной степени полимерности только у их потомства 1-го поколения - у 2-го поколения показатели функциональной активности ниже таковой даже в интактной группе, преимущественно за счет ферментативного звена, однако при этом они не выходят за границы активной компоненты транспорта. Следовательно, для защиты дальнейших поколений от облученных предшественников необходимы более мощные, чем просто пища, радиопротекторы.

Ключевые слова: облучение; тонкая кишка; ассимиляция углеводов; потомство крыс.

\section{O.V. Storchilo}

\section{RADIOPROTECTIVE EFFECT OF FOOD IN THE ASSIMILATION OF CARBOHYDRATE SUBSTRATES BY TWO GENERATIONS OF POSTERITY FROM THE RADIATION- EXPOSED MALE RATS}

The influence of food in the intestine of the radiation-exposed males-predecessors on the functional activity of the small intestine of two generations of their posterity was investigated. It is shown that satiety of these animals during an irradiation determines a radioprotective effect on the systems of transport of carbohydrate substrates of different degree of polymerization only at their posterity of first generation. The second generation had the indexes of functional activity below than that observed in intact group, thus mainly due to a fermentative link. However, here they do not exceed the borders of active component of transport. Consequently, for protection of further generations from the radiation-exposed precursors the more powerful radioprotectors are needed, than simply food. Key words: irradiation, small intestine, assimilation of carbohydrates, rats' posterity.

Odessa National Medical University

\section{REFERENCES}

1. Guryeva VA, Dudareva YuA. The modern estimation of the state of health of descendants of persons being in the zone of radiation-damage (on the example of the Semipalatinsk ground) : Proceeding of the 2 nd International scientific-practical conference "Academic science - problems and achievements", Moscow, September 5-6, 2013, P.273 . [Russian].

2. Dergylev AA, Chibisova OF, Palyga GF, Ivanov VL, Zhavoronkov LP. Influence of ionizing radiation in unsteralizing doses on the embryogenesis and post-natal development of posterity of two generations of rats males, the gametes of that were radiation-exposed on the premeyotic stages of spermatogenesis. Rad. and risk, 2012, 21 ( 2) 39-45 [Russian].

3. Liberman A Radiation and reproductive health. SanctPetersburg, 2003225 p [Russian].

4. Palyga GF, Chibisova OF, Ivanov VL, Dergylev A A, Zhavoronkov LP. Realization of radial effects in the ontogenesis of posterity of two generations of males, whose gametes were radiation-exposed in the nonsterilizide dosage on the stage of mature spermatozoa. 
Rad. and risk 201019 (4) 58-62 [Russian].

5. Palyga GF, Chibisova OF, Ivanov VL, Dergylev A A, Zhavoronkov LP, Panfilova VV, Kolganova OI Realization of radial effects is the ontogenesis of posterity of two generations of males the gametes of which were radiation-exposed singly in unsteralizing doses on the stage of spermatid. Rad. and risk 201120 (1) 19-23 [Russian].

6. Reproductive health of new generation: collection of scientific works of Ivanov Scientifically research institute of maternity and childhood the name of V N Gorodkov of Ministry of health and social development of Russian Federation. 2010. Ivanovo: 382 p. [Russian].

7. Agadganyan AV Investigation of the transgenerational phenomenon of genome instability in the the childrendescendants of the radiation-exposed parents as a result of accident on Chernobyl nuclear power station. Moscow 200820 p. [Russian].

8. Storchilo OV Peculiarialities of the irradiated rats posterity the small intestine functional activity under the parents life-time different conditions. Odessa Med. Mag. 2009 115( 5) 21-27 [Ukrainian].

9. Ugolev AM, Zhigure DR, Nurks EE,. Accumulating preparation of mucous membrane is a new method of research of the initial stages of transfer of substances through an intestinal wall. Physiol. Mag. of the USSR 197056 (11) 1638-1641 [Russian].

10. Scott TA, Melvin EH The determination of hexoses with antrone. Analyt. Chem. 1953 №25, 1656-58.

11. Storchilo OV Functional activity of the small intestine of two generations of the posterity of the hungry irradiated male rats. Odessa Med. Mag. 2013 140(6) 13 -17 [Ukrainian].

Матеріал надійшов

до редакиії 06.06.2014 